\title{
Carbon sequestration and growth of Anthocephalus cadamba plantation in North Kalimantan, Indonesia
}

\author{
AGUS SARJONO, ABUBAKAR M. LAHJIE", B.D.A.S. SIMARANGKIR, R. KRISTININGRUM, \\ YOSEP RUSLIM ${ }^{\vee \bullet}$ \\ Faculty of Forestry, Mulawarman University. J1. Ki Hajar Dewantara, PO Box 1013, Gunung Kelua, Samarinda Ulu, Samarinda-75116, East Kalimantan, \\ Indonesia. Tel./Fax.: +62-541-735379. ^email: lahjie@fahutan.unmul.ac.id, ”vyruslim@gmail.com
}

Manuscript received:28 April 2017. Revision accepted: 31 August 2017.

\begin{abstract}
Sarjono A, Lahjie AM, Simarangkir BDAS, Kristiningrum R, Ruslim Y. 2017. Carbon sequestration and growth of Anthocephalus cadamba plantation in North Kalimantan, Indonesia. Biodiversitas 18: 1385-1393. Forest plantation of Jabon (Anthocephalus cadamba) plays many important roles for the primary source of timber production and also the carbon absorption for environmental amelioration. The growth of A. cadamba trees was measured using the formulas of MAI (Mean Annual Increment) and PAI (Periodic Annual Increment) as the basis of the increment measurement, while the analysis of biomass and carbon with simple linear regression $(\mathrm{y}=\mathrm{a}+\mathrm{bx})$ was used, with the coefficient of $\mathrm{R}^{2}=0.90$. The annual increment of $A$. cadamba trees reached its maximum point or the intersection between MAI and PAI at the age of 8 years, showing the maximum production of $A$. cadamba trees. Forest plantation of A. cadamba produced biomass and carbon sequestration of 81.90 ton $^{-1} \mathrm{a}^{-1}$ and 39.31 ton ha ${ }^{-1}$, respectively at the age of 8 years. However, the amount of biomass and carbon in another plot of $A$. cadamba trees was 96.85 ton ha ${ }^{-1}$ and 46.49 ton ha $^{-1}$, respectively. While the values of the third plot were 116.84 ton $\mathrm{ha}^{-1}$ and 56.08 ton ha $\mathrm{ha}^{-1}$, respectively. The correlation between the diameter and biomass production and the correlation between the age of stands and carbon production were very strong with $\mathrm{R}^{2}$ value was higher than 0.90. This indicated that Jabon (Anthocephalus cadamba) plantation had important roles in carbon sequestration and biomass production.
\end{abstract}

Keywords: Anthocephalus cadamba, biomass, carbon, increment

\section{INTRODUCTION}

Tropical forests play an important role in global carbon sequestration. However, the increasing rate of deforestation and the impact of land-use changes need to be concerned prior to preventing the loss function of tropical forests. This work emphasizes the role of bulk density as the main driver of carbon $(\mathrm{C})$ and nitrogen $(\mathrm{N})$ stock in four land-use categories i.e natural forest, tree plantations, cropland and degraded soil (Tesfaye et al. 2016). In addition, the intense expansion of forest usage as the effect of human activities becomes a main focus to be solved especially the increased use of timber products (Hansen et al. 2013). Therefore, the development of more effective ways to reduce the illegal harvest activities should be done to protect the tropical forest diversity (Ruslim et al. 2016).

Birdsey and Pan (2015) had reviewed on how the function of forest has been changed in recent decades and summarized those implications for global carbon stocks. Although studies of specific management activities, including fertilization system, genotypes and species, site preparation and competition control have been applied in the industrial field trials for decades, the effect of these changes in the ecosystem level and in the interaction between land and atmosphere is still not been focussed, yet. Explicit comparisons of management effects using paired sites are rarely used (Herbst et al. 2015). More often extrapolations are based on the level of land use (Domec et al. 2015). The amount of this nutrient depletion depends on species characteristics, growth rate, tissue nutrient content, the period of harvesting rotation, the use of harvesting methods and nutrient reserves in the soil (Arias et al. 2011).

The mineralization of terrestrial detritus is primarily driven by soil microbes (Hobara et al. 2014; Hawke et al. 2015). The control of nutrient availability for plant uptake and soil microbes also drive $\mathrm{C}$ and $\mathrm{N}$ fluxes to the atmosphere and waterways. Multiple meta-analyses based on hundreds of studies have shown that the addition of $\mathrm{N}$ usually decreases the soil microbes that produce $\mathrm{C}$ ( $\mathrm{Lu}$ et al. 2011). Conversely, $P$ addition can either increase (Liu et al. 2012) or decrease (Groffman and Fisk 2011) forest soil microbial C regardless of the nutrient status of plants growing in the site (Turner and Wright 2014).

Increasing the rotation length would also increase the biomass carbon stock (Gonzalez-Benecke et al. 2015; Sharma et al. 2016; Panwar et al. 2017). The assessment of the whole potential of biomass carbon stock, and other potentials in order to change management activities is urgently needed for balancing the economic productivity with another ecosystem services such as carbon sequestration, the sustainability of soil health and water resources. This is important because the efforts to pursuit different management goals is very costly, but the established tools to evaluate the trade-offs is not ready, yet. (Birdsey and Pan 2015; Law and Waring 2015; Noormets et al. 2015), 
A. Cadamba, one type of local Indonesian plants, is known as popular plants for forest plantation. A. cadamba trees can grow very rapidly with straight stands and its wood is qualified as one of the best raw materials in forestry industries such as plywood, furniture, pulp, paper, board and matches (Mansur and Tuheteru 2011). The nature of tree as carbon sinks is one of the most effective ways to capture greenhouse gas. The ability of fastgrowing species to absorb carbon more rapidly compared with the slow-growing tree species is one of the reason for highly plantation of these trees in the private forest lands (Murdiyarso 2003; Chauhan et al. 2016a). In addition, forest plantation for wood production mostly provides environmental services such as water regulator and carbon absorber (Kanninen 2010; Chauhan et al. 2016b). These services can be sold to beneficiaries parties through Payment for Environmental Services (PES) (Wunder 2005). One of the largest existing environmental services markets is carbon markets through afforestation and reforestation activities in Clean Development Mechanism (CDM), which is integral component of the Kyoto Protocol Framework (Peters-Stanley et al. 2012). Some studies on optimal cycles in the forest plantation revealed that carbon for an environmental service has been included as an income source rather than wood in Europe and America (Van Kooten et al. 1995; Tasson et al. 2004; Galinato and Uchida 2010, 2011; Olschewski and Betitez 2010; Chauhan et al. 2015). Replacing one tree species with another one can considerably alter the functions of key forest ecosystem (Binkley and Menyailo 2005). Differences among species in growth rate, tissue nitrogen (N) concentrations, allocation to wood, foliage, and roots, litter chemistry, and mycorrhizal associations cause differences in net primary productivity (NPP), decomposition, soil carbon (C) storage, and $\mathrm{N}$ cycling (Crowley et al. 2016). However, the sustainability of fast-growing plantations may also be compromised. This occurs when the large amounts of nutrients removed biomass at the end of the rotations can not be compensated by nutrient inputs through fertilization, atmospheric deposition, or nitrogen biological fixation (Laclau et al. 2010). Therefore, this study aimed to analyze the increment of A. cadamba forest plant, and analyze the effect of forest plantation of A. cadamba on the production of biomass and carbon indicated by the value of coefficient of determination.

\section{MATERIALS AND METHODS}

\section{Study site}

The experiment was conducted from December 2015 to March 2016 in A. cadamba plantation area of Intracawood Manufacturing Company, North Kalimantan, Indonesia. The field experiments were conducted in four plots of $A$. cadamba plantation sites with the age of 8 years.

The area was located at a longitude of $116^{\circ}, 47^{\prime} 21,0^{\prime \prime}$ East and at a latitude of $0^{\circ} 30^{\prime} 04,7^{\prime \prime}$ North and at an elevation of $40-50 \mathrm{~m}$ above sea level. The annual temperature ranged between $27-30^{\circ} \mathrm{C}$ and annual rainfall was about $3,710.5 \mathrm{~mm}$.

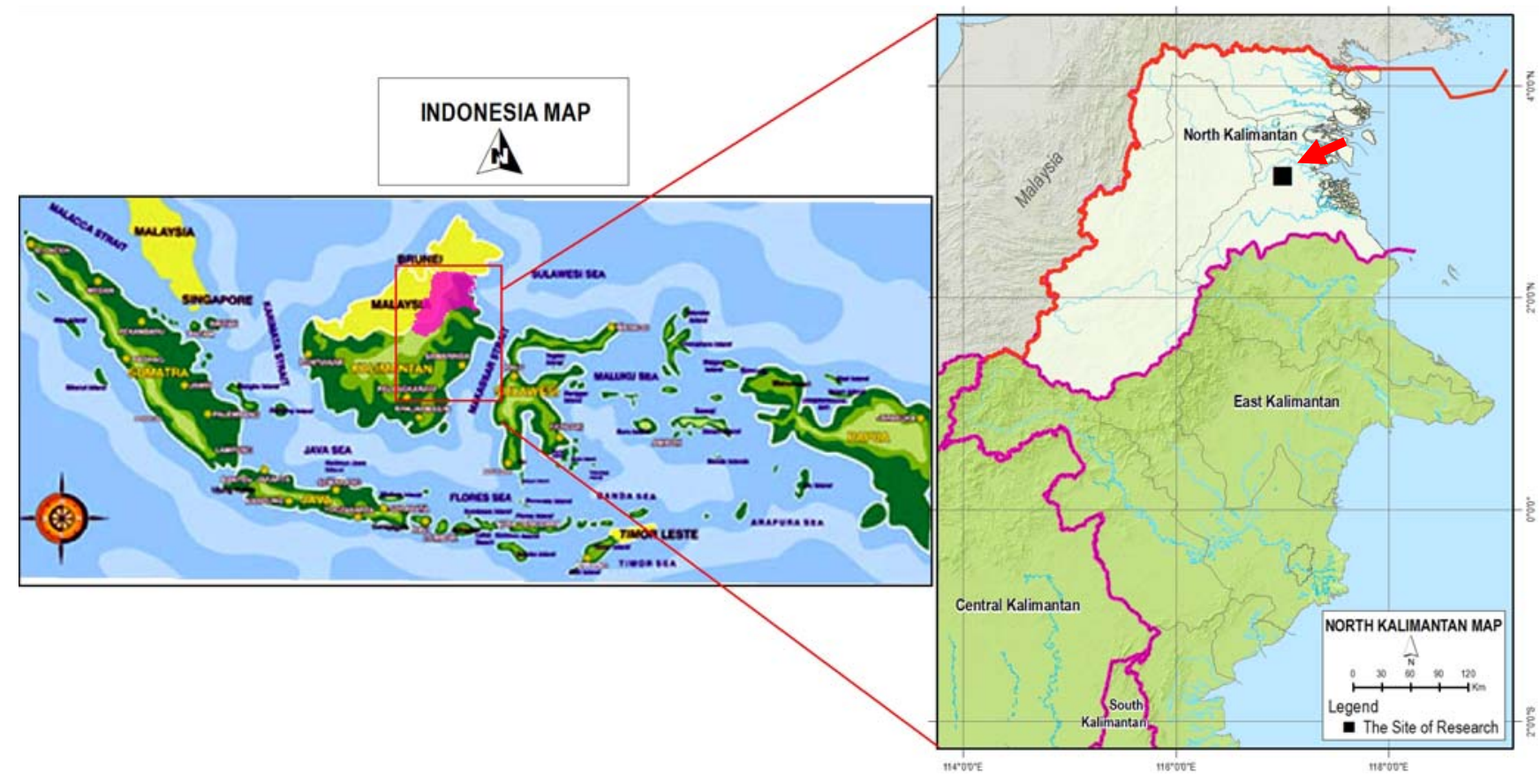

Figure 1. Location studies of Intraca manufacturing company ( $\mathbf{a})$ of North Kalimantan, Indonesia 


\section{Plot setting}

Each plot had an area of $100 \mathrm{~m} \times 100 \mathrm{~m}$ with a spacing of $4 \mathrm{~m} \times 4 \mathrm{~m}$. A. cadamba research plot consists of 3 (three) plots, ie. plot 1 as a control in the first year was given the manure fertilizer (bokashi) and NPK with the same dosage as the plot 2 and plot 3 with the value of fertilizer was 3-4 times from the price of biomass. For the advanced age, the plants were supplied with different fertilizer. Differences of fertilization doses in the second and subsequent years depended on the production of biomass (PAI). Differences in the economic value of fertilizer depended on Periodic Annual Increment (PAI) in that year. The dose of fertilizer was given to medium production ranged from $20-90 \%$ or the average total economic value of fertilizer $55 \%$ of biomass PAI (where young trees have the highest percentage). While at the maximum dose, the economic value ranged from 15 to $90 \%$ or the average total economic value of fertilizer $44 \%$ of biomass PAI where the price of manure IDR $1,000 \mathrm{~kg}^{-1}$ and NPK IDR $5,000 \mathrm{~kg}^{-1}$.

\section{Research procedure}

Plot 1 was used to control the biomass and the growth, plot 2 and plot 3 were used to research and each stand age was used to evaluate the tree growth and to estimate its biomass production. The stem diameter at breast height (D; $1.3 \mathrm{~m}$ above the ground) and the tree height $(\mathrm{H})$ of all $A$. cadamba trees were measured in the plots. The girth was measured using a tape. The diameter and the height was measured by Suunto clinometer.

The sample of the soil was firstly taken by determining the point of sample in the research plots. The soil composite samples were taken using a hoe or a shovel. The ground was dug up $30 \mathrm{~cm}$ deep, and then the soil sample was collected around $1 \mathrm{~kg}$ using a trowel.

\section{Data analysis}

\section{Estimating MAI and PAI}

According to Van Gardingen et al. (2003), to estimate the mean annual increment (MAI) and the periodic annual increment, the following mathematic formulas were used:

$$
\begin{aligned}
& \text { MAI }=\frac{\mathrm{vt}_{\mathrm{t}}}{\mathrm{t}} \\
& \text { MAI }=\text { Mean annual increment } \\
& \mathrm{V}_{\mathrm{t}}=\text { Total volume in ages } \mathrm{t}_{0}-\mathrm{t}\left(\mathrm{m}^{3}\right) \\
& \mathrm{t} \quad=\text { Ages (years) } \\
& \text { PAI }-\frac{V_{\mathrm{t}}-V_{\mathrm{t}-1}}{\mathrm{~T}}
\end{aligned}
$$

PAI = Periodic annual increment

$\mathrm{V}_{\mathrm{t}}=$ Total volume in ages $\mathrm{t}_{0}-\mathrm{t}\left(\mathrm{m}^{3}\right)$

$\mathrm{V}_{\mathrm{t}-1}=$ Previous total volume $\left(\mathrm{m}^{3}\right)$

$\mathrm{T}=$ Second age $\mathrm{t}_{0}-\mathrm{t}$, minus the first age (in year)

\section{The estimation of tree biomass}

The tree biomass can be expressed as the average of mass per unit area, or as the total of mass in the community. To formulate allometric equation for trees, about 10 different diameter-sized trees were cut down around the plots. This study was carried out through the destructive sampling technique of plant age on the level of A. cadamba started at 2 years old. To estimate the biomass of forest plants, the diameter and the height of the whole plants in an area $(100 \mathrm{~m} \times 100 \mathrm{~m})$ were measured and the measurements were repeated three times. To build the allometric equation, this criterion was used: if the value of $\mathrm{R}^{2}$ was high, then the variables had a strong correlation (Arezoo et al. 2014). Similarly, Chastain et al. 2006 used allometric modeling of the above ground biomass to quantify the importance of Kalmia latifolia and Rhododendron maximum, relative to stratum tree stands, in driving biogeochemical cycle in the Central Appalachian Mountains. Carbon sequestration and nitrogen and phosphorus storage potentials were investigated by running 50-year simulations of the ecosystem accounting model NuCSS for two situations: forests comprising the canopy over story layer with or without the evergreen understory layer (Darch et al. 2016). In addition to the quantity of the tree diameter and height, each of logs, branches, and twigs, leaves, and roots were also measured for its diameter and weight (Waring and Powers 2017). To find out the biomass of individual plant parts, about 250 grams of dried sample was taken and it was based on the ratio of wet weight and dry weight. Thus, the biomass per tree, parts of the stem, branches, and twigs, leaves and the total biomass can be estimated (Waring and Powers 2017). Biomass per plot is the sum of each individual tree biomass contained in the swaths of the designated study. Through the conversion of land coverage area, the accumulation of biomass or carbon content per hectare can be identified (Hardwick et al. 2015).

\section{RESULTS AND DISCUSSIONS}

\section{Growth of $A$. cadamba stands}

White Jabon (A. cadamba) can be cultivated in the different tread conditions (Haneda et al. 2012) and have significant exhibits on early growth of cultivation. However, the plants are threatened by the factor of excess water (Dunisch et al. 2003). Specifically, white jabon is very susceptible to water shortages, or not suitable for the rehabilitation of critical land.

The intensity of waterlogging and drought are predicted to increase in dry and rainy seasons due to climate change (Tong et al. 2016) and potentially affects on initial growth and successful forest and land rehabilitation activities. This condition can be used as reference in the development of seeds as well as a key climate change adaptation strategy (Millar et al. 2007). Jabon putih (A. cadamba) is a native forest species of South and Southeast Asia (Orwa et al. 2009). The characteristics of this species are quickly growth, straight growth, cylindrical boles, small diameter 
branches and easily perform self-pruning. Jabon wood is very versatile as for plywood, light building materials, flooring, beams and rafters, boxes and wooden crate, wooden chests, packing boxes, coverings, ceiling boards, toys, wooden shoes, coils, shackles, carvings, chopsticks and pencils (Soerianegara and Lemmens 1993). In Indonesia, this species has been cultivated in West Java, East Java, South Kalimantan, East Kalimantan, Sumatra, Sulawesi, West Nusa Tenggara, and Papua (Martawijaya et al. 1989).

Detailed growth of A. cadamba from plot one plot two and plot three is presented in Table 1. According to Indrayana et al. (2013), A. cadamba trees cultivated in Java had the mean annual volume with the increment of $21 \mathrm{~m}^{3}$ $\mathrm{ha}^{-1}$ year $^{-1}$, whereas, Krisnawati et al. (2011) stated that the mean annual volume of $A$. cadamba in small farms in South Kalimantan at the age of 9, reached $20 \mathrm{~m}^{3} \mathrm{ha}^{-1}$ year ${ }^{-1}$. In this research, the maximum average increment at age 8 in plot one $20.47 \mathrm{~m}^{3} \mathrm{ha}^{-1}$ year $^{-1}$, in plot two $24.21 \mathrm{~m}^{3} \mathrm{ha}^{-1}$ year ${ }^{-1}$, in plot $329.21 \mathrm{~m}^{3} \mathrm{ha}^{-1}$ year $^{-1}$. Can be seen in Table 1.

The average diameter of $A$. cadamba approximately 13 $\mathrm{cm}$ at age 5 . While in this research, in plot one $22.7 \mathrm{~cm}$, in plot two $23.4 \mathrm{~cm}$ and in plot three $26.2 \mathrm{~cm}$. The mean of total height is $11 \mathrm{~m}$, whereas in this research the clear bole height in the $5.8 \mathrm{~m}$ plot (total height $9 \mathrm{~m}$ ), in the plot two clear bole height $6 \mathrm{~m}$ (total height of $9.6 \mathrm{~m}$ ), in plot three clear bole height $7 \mathrm{~m}$ (total height $10.8 \mathrm{~m}$ ). To estimate these difference factors, in South Kalimantan have rainfall 2200-2700 mm year ${ }^{-1}$ while in the location of this study 3200-3700 mm year ${ }^{-1}$. Another factor, the density of plants in one hectare more in South Kalimantan, therefore the total height of $A$. cadamba is higher.

What is interesting in the data table above is the Mean Annual Increment (MAI) precisely in year 8, where the MAI and PAI are equal in value even though the total of increment is different i.e. in plot one $163.79 \mathrm{~m}^{3} \mathrm{ha}^{-1}$ year $^{-1}$ in plot two $193.71 \mathrm{~m}^{3} \mathrm{ha}^{-1}$ year $^{-1}$ and on the plot three
$233.68 \mathrm{~m}^{3} \mathrm{ha}^{-1}$ years ${ }^{-1}$. This difference is known because of differences in fertility resulting from fertilization and silvicultural techniques by thinning. Seen on plot one number of tree 460 diameter $30 \mathrm{~cm}$ at age 8 , in plot two number of tree 450 diameter $32.3 \mathrm{~cm}$ and in plot 3 number of tree 430 diameter $33.6 \mathrm{~cm}$. According to Seo et al. (2015) the three plots are considered good growth.

\section{The effect of fertilization on the increment growth of A. cadamba}

Seo et al. (2015) has divided three categories of $A$. cadamba growth research in West Java into good growth in white jabon age 3.5 years diameter ranging from $15-17 \mathrm{~cm}$, growth medium diameter ranged from $11-13 \mathrm{~cm}$, poor growth 5-7 cm. In West Java, the most widely used fertilizers are NPK fertilizer, animal manure (bokashi), urea were widely applied and few TSP in some places. In general, the initial fertilization done at the time with the amount of fertilizer 15 grams per seedling. In South Kalimantan, urea and TSP are widely used at the time of growth of jabon age 2 . Thus, at $3 \mathrm{~m} \times 3 \mathrm{~m}$ spacing the amount of inorganic fertilizer reaches $15 \mathrm{~kg} \mathrm{ha}^{-1}$. In this research, initial fertilization was done on three plots, $56 \mathrm{~g}$ seedling $^{-1}$ NPK fertilizer and $1 \mathrm{~kg}$ animal manure seedling${ }^{1}$. While the subsequent fertilization depends on the amount of increment and estimated price of stem biomass. In this study, it is not based on high increments and diameters but is based on increment volume stands or trees.

The increments of $A$. cadamba in each plot were different because of the different fertilizer applications in plot two and plot three. Plot one as the control plot was not fertilized, while plot two and plot three were fertilized to find out if there was any effect of fertilization on the growth of A. cadamba. The types of fertilizer applied were bokashi and NPK. The dosage and effect of the fertilizer can be seen in Table 2 .

Table 1. The volume of A. cadamba in plot one (control plot), plot two and plot three

\begin{tabular}{|c|c|c|c|c|c|c|c|c|c|c|c|c|c|c|c|c|c|c|c|c|c|}
\hline \multirow{2}{*}{ Ages } & \multicolumn{7}{|c|}{ Plot 1} & \multicolumn{7}{|c|}{ Plot 2} & \multicolumn{7}{|c|}{ Plot 3} \\
\hline & $\mathbf{N}$ & d & h & F & TV & IAI & $\Delta \mathbf{I}$ & $\mathbf{N}$ & d & h & $\mathbf{F}$ & TV & IAI & $\mathbf{A I}$ & $\mathbf{N}$ & d & h & $\mathbf{F}$ & TV & IAI & $\mathbf{P A}$ \\
\hline & & & 4.0 & & & & & & & & & & & & & & & & & & \\
\hline 3 & & & 4.8 & & & & & & & 4.7 & & & & & & & 5.7 & & & & \\
\hline 4 & & & 5.5 & & & & & & & 5. & & & & & 0 & 20.0 & 6.3 & & & & \\
\hline 5 & 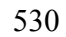 & 2.7 & 5.8 & 0.74 & & & & & 23.4 & 6.0 & 0.74 & & & & & 24.0 & 7.0 & 6 & & & 41.31 \\
\hline & & & & & & & & & 07 & 6.6 & & & & & & & 8.0 & & & & 39.8 \\
\hline 7 & 480 & 8.3 & 6.6 & 0.72 & & & & & & 7.0 & 0.73 & & & & & 30.0 & 8.2 & 0.74 & & & 40.8 \\
\hline 8 & 460 & & 7.0 & 0.72 & & & 2 & & 32.3 & 7.3 & 0.72 & & 24.21 & & & 33.6 & 8.4 & 0.73 & 233.68 & & 27.90 \\
\hline 9 & & & 7.2 & 0.71 & & & $7.1^{\prime}$ & & & 7.4 & 0.72 & & 22 & & & & 8.6 & 0.72 & 243.65 & & 9.97 \\
\hline & 440 & 31.1 & 7.5 & 0.70 & 174.47 & 17.45 & 3.50 & 430 & 34.1 & 7.5 & 0.71 & 205.97 & 20.60 & 4.05 & 380 & 36.5 & 8.8 & 0.71 & 248.30 & 24.83 & 4.65 \\
\hline
\end{tabular}

Notes: $\mathrm{N}=$ Population of $A$. cadamba $\left(\right.$ tree ha $\left.^{-1}\right), \mathrm{d}=$ Tree Diameter $(\mathrm{cm}), \mathrm{h}=$ clear bole height $(\mathrm{m}), \mathrm{F}=$ form factor, $\mathrm{TV}=$ Total Volume $\left(\mathrm{m}^{3} \mathrm{ha}^{-1}\right)$, MAI $=$ Mean Annual Increment $\left(\mathrm{m}^{3} \mathrm{ha}^{-1}\right.$ year $\left.^{-1}\right)$, PAI $=$ Periodic Annual Increment $\left(\mathrm{m}^{3} \mathrm{ha}^{-1}\right.$ year $\left.{ }^{-1}\right)$ 
Table 2. The Effect of fertilization dosage on the growth of $A$. cadamba plot two and three

\begin{tabular}{|c|c|c|c|c|c|c|c|c|c|c|c|c|}
\hline \multirow{2}{*}{$\begin{array}{c}\text { Age } \\
\text { (year) }\end{array}$} & \multicolumn{6}{|c|}{ Plot 2} & \multicolumn{6}{|c|}{ Plot 3} \\
\hline & PAI 1 & PAI 2 & $\begin{array}{c}\text { Difference } \\
\text { PAI }\end{array}$ & Price & NPK & Bokashi & PAI 1 & PAI 3 & $\begin{array}{c}\text { Difference } \\
\text { PAI }\end{array}$ & Price & NPK & Bokashi \\
\hline & \multicolumn{3}{|c|}{$\left(m^{3} h^{-1}\right.$ year $\left.^{-1}\right)$} & $\left(\mathrm{Rp} .1,000 \mathrm{~m}^{-3}\right)$ & \multicolumn{2}{|c|}{$\left(\mathrm{kg} \mathrm{ha}^{-1}\right)$} & \multicolumn{3}{|c|}{$\left(m^{3} h^{-1}\right.$ year $\left.^{-1}\right)$} & $\left(\mathrm{Rp} .1,000 \mathrm{~m}^{-3}\right)$ & \multicolumn{2}{|c|}{$\left(\mathrm{kg} \mathrm{ha}^{-1}\right)$} \\
\hline 1 & 13.15 & 14.01 & 0.86 & 270 & 35 & 625 & 13.15 & 15.18 & 2.03 & 270 & 35 & 625 \\
\hline 2 & 16.81 & 17.55 & 0.74 & 300 & 10 & 100 & 16.81 & 18.36 & 1.55 & 300 & 20 & 300 \\
\hline 3 & 20.05 & 21.00 & 0.95 & 350 & 20 & 200 & 20.05 & 21.79 & 1.74 & 350 & 40 & 400 \\
\hline 4 & 21.24 & 22.6 & 1.36 & 350 & 30 & 300 & 21.24 & 29.01 & 7.77 & 350 & 60 & 600 \\
\hline 5 & 23.60 & 26.57 & 2.97 & 400 & 50 & 500 & 23.6 & 41.31 & 17.71 & 400 & 80 & 900 \\
\hline 6 & 26.14 & 35.86 & 9.72 & 400 & 90 & 600 & 26.14 & 39.80 & 13.66 & 400 & 120 & 1100 \\
\hline 7 & 25.25 & 34.58 & 9.33 & 500 & 60 & 800 & 25.25 & 40.89 & 15.64 & 500 & 80 & 900 \\
\hline 8 & 20.39 & 24.03 & 3.64 & 500 & 40 & 300 & 20.39 & 27.90 & 7.51 & 500 & 50 & 600 \\
\hline 9 & 7.17 & 8.01 & 0.84 & 550 & 30 & 100 & 7.17 & 9.97 & 2.80 & 550 & 30 & 300 \\
\hline 10 & 3.50 & 4.20 & 0.70 & 600 & 20 & 90 & 3.50 & 4.65 & 1.15 & 600 & 20 & 200 \\
\hline
\end{tabular}

Notes: PAI 1= Periodic annual increment of A. cadamba in plot 1, PAI 2 = Periodic annual increment of A. cadamba in plot 2 and PAI 3 $=$ Periodic annual increment of $A$. cadamba in plot 3

Table 2 showed that the increment growth of $A$. cadamba in plot 2 was affected by the different dosages of NPK and bokhasi fertilization. This was indicated by the fact that the average periodic annual increment of $A$. cadamba in plot two was higher than that in plot one. The PAI of $A$. cadamba in plot two reached its maximum increment at the age of 6 years with the growth rate of $35.86 \mathrm{~m}^{3} \mathrm{ha}^{-1}$ year $^{-1}$. The different values of PAI which started from the age of 1 year to 10 years were $0.86 ; 0.74$; $0.95 ; 1.36 ; 2.97 ; 9.72 ; 9.33 ; 3.64 ; 0.84$ and $0.7 \mathrm{~m}^{3} \mathrm{ha}^{-1}$ year ${ }^{1}$ respectively. The dosages of NPK fertilizer were different for different ages. The fertilizer was applied to the trees aged 2 to 7 years with the increasing dosages of $10 \mathrm{~kg} ; 20$ $\mathrm{kg} ; 30 \mathrm{~kg}, 50 \mathrm{~kg} ; 90 \mathrm{~kg} ; 60 \mathrm{~kg}$ in each hectare for each year. After the trees had reached the age of 7 , the dosage of fertilizer was reduced to $40 \mathrm{~kg} ; 30 \mathrm{~kg}$ and $20 \mathrm{~kg}$. This followed the law of diminishing returns. The dosages of bokhasi fertilizer application were also different. At the age of 2 to 7 years the dosages were increased, and when the trees reached the age of 8 years, the dosages of bokhasi fertilizer were reduced. The amount of fertilizer applied was based on the total income derived from timber sales. The percentage of bokhasi fertilizer application was $60 \%$, higher than the percentage of NPK fertilizer application which was only $40 \%$.

Table 2 showed that the increment of $A$. cadamba in plot 3 was effected by the different dosages of NPK and bokhasi fertilizer application. This can be seen from the periodic annual increment of $A$. cadamba in plot three which was higher than that in plot one. The PAI of $A$. cadamba in plot three also reached its maximum increment at the age of 6 with the increment of $43.76 \mathrm{~m}^{3} \mathrm{ha}^{-1} \mathrm{year}^{-1}$. The different values of PAI reached at the age of 1 year to 10 years were $2.03 ; 1.55 ; 1.74 ; 7.77 ; 17.71 ; 13.60 ; 15.64$; $7.51 ; 2.8$; and $1.15 \mathrm{~m}^{3} \mathrm{ha}^{-1}$ year $^{-1}$ respectively. The dosages of NPK fertilizer application were different according to the tree ages, which began at the age of 2 years to 6 years with the increasing dosages of $20 \mathrm{~kg} ; 40 \mathrm{~kg} ; 60 \mathrm{~kg}$, $80 \mathrm{~kg}$ and $120 \mathrm{~kg}$, and after reaching the age 7 years, the dosages of NPK fertilizer application were reduced to $80 \mathrm{~kg} ; 50 \mathrm{~kg}$; $30 \mathrm{~kg}$ and $20 \mathrm{~kg}$. This followed the law of diminishing returns. The application of bokashi fertilizer was also different. At the age of 2 to 6 years, the dosages were increased, and when the trees reached the age of 7 years, the dosages of bokhasi fertilizer were reduced. The amount of fertilizer applied to A. cadamba in plot three was the same as the amount of fertilizer applied to A. cadamba in plot two, namely it was based on the total income derived from timber sales. The percentage of bokhasi fertilizer application was $70 \%$, higher than the percentage of NPK fertilizer application which was just $30 \%$.

The addition of fertilizer in plot two, the result shows higher economic value $(18.3 \%)$ compared to plot one. The addition of the fertilizer in plot three also shows higher economic value $(24.4 \%)$ compared to plot one. However, the comparison of economic value between plot two and three is $6.1 \%$. Futhermore, the result shows that the maximum of the amount of fertilizer is found in plot three.

\section{Biomass in revegetation area}

Biomass is closely related to the process of photosynthesis. Biomass increases because the plant absorbs $\mathrm{CO}_{2}$ from the air and transforms it to organic compounds through the process of photosynthesis. The result of photosynthesis is used by plants to grow horizontally and vertically (Adinugroho and Sidiyasa 2009). Based on the growth volume of $A$. cadamba in all plots, it was found that there was a correlation between biomass and litter, between litter and age, and between litter and basal area. Therefore, the analysis of simple linear regression was needed. To measure the precision of the regression line which was used to identify the variability of data explained by the regression model, coefficient of determination was required, which was symbolized as $\mathrm{R}^{2}$. The maximum value of $\mathrm{R}^{2}$ was $100 \%$, and the minimum value was $0 \%$, with the following criteria: if the value of $\mathrm{R}^{2}$ was high then there was a strong correlation between $\mathrm{X}$ and $\mathrm{Y}$ or if $\mathrm{R}^{2}=0$, then there was no 
any correlation between $\mathrm{X}$ and $\mathrm{Y}$. If the value of $\mathrm{R}^{2}$ was low, then the correlation between $\mathrm{X}$ and $\mathrm{Y}$ was weak (Handayani 2010). In addition, if the value of coefficient of determination $\left(\mathrm{R}^{2}\right)$ showed a precise and strong correlation between the independent and dependent variables, then according to this criterion, it could give greater confidence on the acceptance of model. The high value of $\mathrm{R}^{2}$ means that there was a strong correlation between the variables (Grafen and Hails 2002; Arezoo et al. 2014).

Table 3 showed the data of the correlation of basal area, biomass, litter, and carbon of A. cadamba in plot one as a control plot. The older the age of one stand, the higher its value would be or it means that the value of a stand and its age were directly proportional. The values of biomass, litter, and carbon of A. cadamba in plot one at the age of 8 were 81.90 ton ha ${ }^{-1} ; 2,500 \mathrm{~kg} \mathrm{ha}^{-1}$ and 39.31 ton $\mathrm{ha}^{-1}$ respectively. The correlation can be seen in Figure 2 .

Figure 2 showed that there was a very strong correlation and linear between carbon and litter, basal area and biomass of $A$. cadamba in plot one. The value of coefficient of determination $\left(\mathrm{R}^{2}\right)$ between carbon and biomass was 0.98.; the value of coefficient of determination $\left(\mathrm{R}^{2}\right)$ between carbon and basal area was 0.99 , and the value of $\left(\mathrm{R}^{2}\right)$ between carbon and litter was 0.96 . This indicated that there was a strong correlation between carbon and basal area also between biomass and litter because the value of coefficient of determination was higher than 0.90 . The graph of each correlation formed a liner shape. This means that the older the age of an $A$. cadamba tree, the higher the content of its carbon, litter, biomass and basal area. The correlation of Basal Area, Biomass, Litter, and Carbon of A. cadamba in Plot two can be seen in Table 3.

Table 3 showed that there was a very strong correlation between carbon and litter, basal area and biomass of $A$. cadamba in plot two and the correlation form a linear shape. Graphically, the correlations can be seen in Figure 3, in which the value of $\mathrm{R}^{2}$ for the correlation between carbon and biomass was 0.99; the value of $\mathrm{R}^{2}$ for the correlation between carbon and basal area was 0.99 , and the value of
$\mathrm{R}^{2}$ for the correlation between carbon and litter was 0.97 . This indicated that there was a strong correlation between carbon and basal area, biomass and litter because the value of its coefficient of determination was higher than 0.90 and the graph of each correlation formed a linear shape. This means that the older the age of an A. cadamba tree, the higher the content of its carbon, litter, biomass and basal area. The amount of biomass, litter, and carbon of $A$. cadamba in plot two at the age of 8 were 96.85 ton ha $^{-1}$; $3,020 \mathrm{~kg} \mathrm{ha}^{-1}$ and 46.49 ton ha ${ }^{-1}$ respectively.

The data concerning the correlation of basal area, biomass, litter, and carbon can be seen in Table 3 . Table 3 showed the correlation of basal area, biomass, litter and carbon of $A$. cadamba in plot three, which had a linear correlation. This means that the older the age of one stand, the higher the content of its biomass, litter and carbon. This is supported by Figure 4 which shows that the correlation between carbon and litter, and between basal area and biomass of $A$. cadamba in plot three was very strong and linear. The value of $\mathrm{R}^{2}$ for the correlation between carbon and biomass was 0.99 ; the value of $\mathrm{R}^{2}$ for the correlation between carbon and basal area was 0.99 , and the value of $\mathrm{R}^{2}$ for the correlation between carbon and litter was 0.96 . This means that there was a strong correlation between the content of carbon and basal area of A. cadamba trees in plot three and there was a strong correlation between biomass and litter because the values of their regression coefficients were higher than 0.90 and the graph of each correlation formed a linear shape. This means that the older the age of an A. cadamba tree, the higher the content of its carbon, litter, biomass, and basal area. The amount of biomass, litter, and carbon of A. cadamba in plot three at the age of 8 was 116.84 ton $\mathrm{ha}^{-1} ; 3.650 \mathrm{~kg} \mathrm{ha}^{-1}$ and 56.08 ton ha $^{-1}$ respectively.

Based on Figure 2, 3 and 4, it can be concluded that the correlations between carbon and biomass, between litter and basal area in all research plots, were very strong and linear because the value of regression coefficient $\left(\mathrm{R}^{2}\right)$ was higher than 0.90 .

Table 3. The correlation of basal area, biomass, litter, and carbon of A. cadamba in plot one, plot two and plot three

\begin{tabular}{|c|c|c|c|c|c|c|c|c|c|c|c|c|}
\hline \multirow{2}{*}{$\begin{array}{c}\text { Ages } \\
\text { (year) }\end{array}$} & \multicolumn{4}{|c|}{ Plot $1 /$ control } & \multicolumn{4}{|c|}{ Plot 2} & \multicolumn{4}{|c|}{ Plot 3} \\
\hline & $\begin{array}{c}\text { Basal area } \\
\left(\mathrm{m}^{2}\right)\end{array}$ & $\begin{array}{c}\text { Biomass } \\
\left(\text { ton ha }^{-1}\right)\end{array}$ & $\begin{array}{c}\text { Litter } \\
\left(\mathrm{kg} \mathrm{ha}^{-1}\right)\end{array}$ & $\begin{array}{c}\text { Carbon } \\
\left(\text { ton ha }{ }^{-1}\right)\end{array}$ & $\begin{array}{c}\text { Basal area } \\
\left(\mathrm{m}^{2}\right)\end{array}$ & $\begin{array}{c}\text { Biomass } \\
\left.\text { (ton ha }^{-1}\right)\end{array}$ & $\begin{array}{c}\text { Litter } \\
\left(\mathrm{kg} \mathrm{ha}^{-1}\right)\end{array}$ & $\begin{array}{c}\text { Carbon } \\
\left(\text { ton ha }^{-1}\right)\end{array}$ & $\begin{array}{c}\text { Basal area } \\
\left(\mathrm{m}^{2}\right)\end{array}$ & $\begin{array}{c}\text { Biomass } \\
\left.\text { (ton ha }^{-1}\right)\end{array}$ & $\begin{array}{c}\text { Litter } \\
\left(\mathrm{kg} \mathrm{ha}^{-1}\right)\end{array}$ & $\begin{array}{c}\text { Carbon } \\
\left(\text { ton ha }^{-1}\right)\end{array}$ \\
\hline 2 & 8.69 & 12.75 & 1,080 & 5.74 & 8.92 & 14.07 & 1,184 & 6.33 & 8.92 & 15.50 & 1,300 & 6.98 \\
\hline 3 & 12.93 & 22.41 & 1,250 & 10.20 & 14.02 & 23.78 & 1,300 & 10.82 & 12.52 & 25.71 & 1,350 & 11.70 \\
\hline 4 & 16.59 & 32.84 & 1,480 & 15.11 & 17.62 & 34.88 & 1,540 & 16.05 & 17.27 & 40.21 & 1,800 & 18.50 \\
\hline 5 & 21.44 & 44.63 & 1,800 & 20.75 & 22.35 & 48.13 & 1,920 & 22.38 & 21.25 & 58.75 & 2,350 & 27.32 \\
\hline 6 & 2 & 57. & 2, & 27 & & 66.20 & 2,380 & & & 80.80 & 2,900 & 37.97 \\
\hline 7 & 3 & 70 . & & & & 83.99 & 2,800 & & & 101.18 & 3,360 & 48.06 \\
\hline 8 & 32.50 & 81.9 & & & & 96.85 & 3,020 & & 38.11 & 116.84 & 3,650 & 56.08 \\
\hline 9 & 33.44 & 86.34 & 2,450 & 41.87 & & 101.21 & 2,950 & 49.08 & 39.35 & 123.04 & 3,500 & 59.68 \\
\hline 10 & 33.62 & 89.45 & 2,350 & 43.83 & 38.68 & 102.88 & 2,850 & 50.41 & 39.40 & 125.94 & 3,450 & 61.71 \\
\hline
\end{tabular}




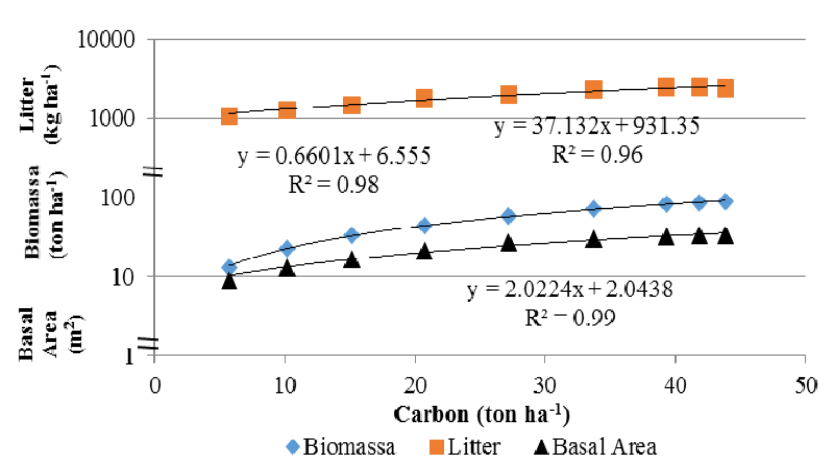

Figure 2. The Correlation between carbon and litter and basal area and biomass of $A$. cadamba in plot one

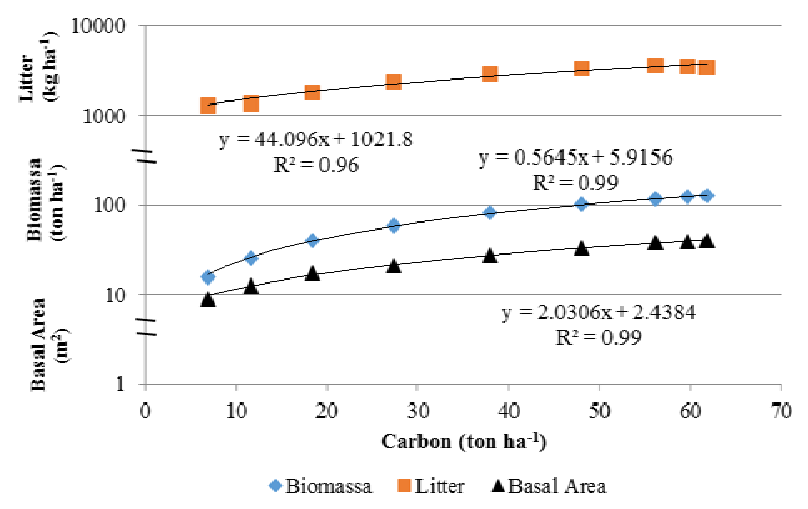

Figure 3. The correlation between carbon and litter, basal area and biomass of $A$. cadamba in plot two

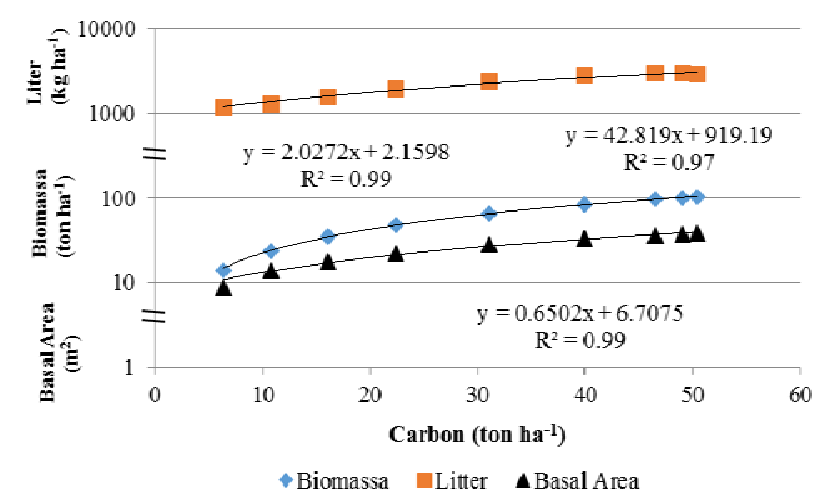

Figure 4. The correlation between carbon and litter, between basal area and biomass of $A$. cadamba in plot three

\section{Carbon and biomass production}

As the trees were getting older, their ability to absorb carbon was also high. Therefore, age was very influential on the production of carbon. The stand age, in relation to its influence on carbon sequestration, had a very strong and high correlation $\left(\mathrm{R}^{2}\right)$, reaching 0.90 (Figure 5). The tree phase was able to absorb more carbon compared with the pole phase, sapling phase, and seedling phase. The factor which influences the ability of a tree in storing carbon is the age of the tree (Mansur dan Tuheteru 2011).

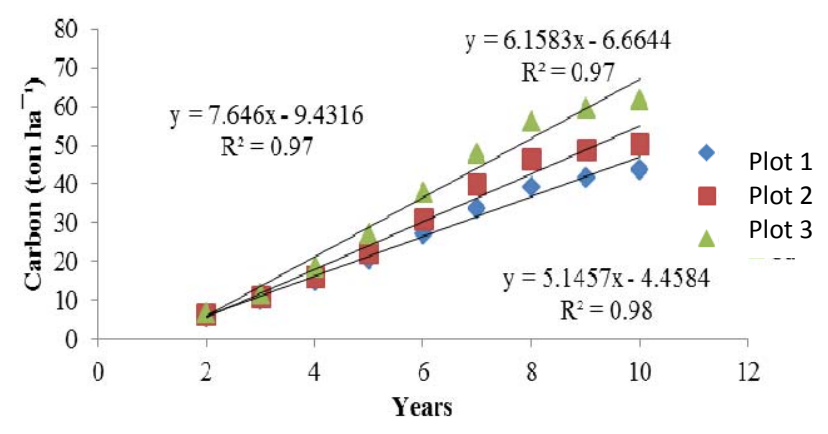

Figure 5. The correlation between the stand age of A. cadamba and the production of carbon

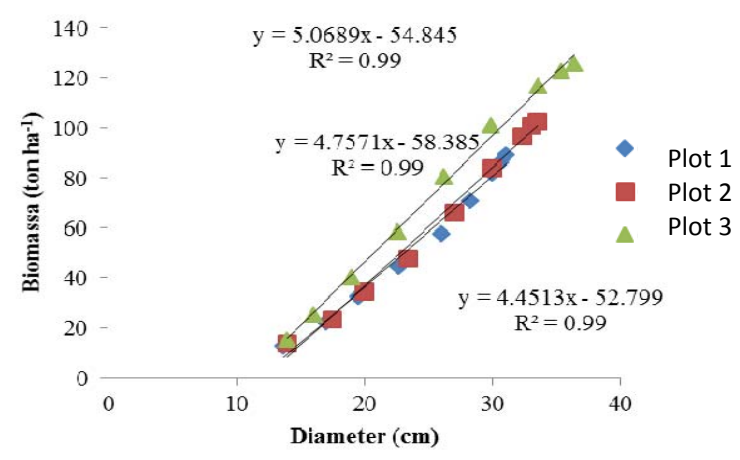

Figure 6. The correlation between diameter and biomass in the research plots

Tree age is closely related with tree stratification. The higher the stratification of a tree, the older the tree will be. The main differences of stratification level are the diameter and height of the tree. The older the age of a tree, the larger its diameter and the higher its trunk will be (Mansur and Tuheteru 2011). The same is applied to the diameter and biomass of a tree. The larger the diameter of one stand, the more biomass it will produce. Figure 6 showed a very significant correlation because the value of its $\mathrm{R}^{2}$ reached 0.90 .

Each plot produced different amount of biomass. Plot one as the control plot produced a very small amount of biomass compared with the production of biomass in plot two and plot three. This is indicated by the diameter which grew larger in plot two and plot three. Thus, forest plantation of A. cadamba plays important roles in absorbing carbon from the air and in producing biomass as the replacement of natural forests. A. cadamba is a tree that absorbs many nutrients, so it needs integration with cattle farms as a source of organic fertilizer. In 2.5 hectares $A$. cadamba trees required 1 cow to produce organic fertilizer. Organic fertilizer alone is not enough to accelerate the growth of A. cadamba trees, so it is necessary also an organic fertilizer as a decomposition stimulator. Economically, the total value of organic and an organic fertilizer is $30 \%$ from A. cadamba stem biomass margin growth value that can be utilized for timber industry. Fertilization is given to A. cadamba trees in a balanced manner. The comparison of organic economic value versus anorganic 7:3. 


\section{ACKNOWLEDGEMENTS}

We would like to extend our gratitude to the Director and all of the staffs of Intraca Hutani Lestari company, who have allowed us to conduct research on the site. Our gratitude also goes to Satria Yudha Prijanto, who has helped us in accomplishing this research and Umbar Sujoko for his help in creating the map of the study site.

\section{REFERENCES}

Arias D, Alvarado J, Richter DJ, Dohrenbusch A. 2011. Productivity, aboveground biomass, nutrient uptake and carbon content in fastgrowing tree plantations of native and introduced species in the Southern Region of Costa Rica. Biomass Bioenerg 35: 1779-1788.

Arezoo S, Sankhayan PL, Hofstad O. 2014. A dynamic bio-economic model for community management of goat and oak forests in Zagros, Iran.J Ecol Econ 106: 174-185.

Adinugroho WC, Sidiyasa K. 2009. Biomass estimation model of above ground Mahogany (Swietenia macrophylla King) Tree. http://wahyukdephut.wordpress.com. [Indonesian]

Binkley D, Menyailo O (eds). 2005. Tree Species Effects on Soils: Implications for Global Change. NATO Science Series, Kluwer, Dordrecht.

Birdsey R, Pan Y. 2015. Trends in management of the world's forests and impacts on carbon stocks. For Ecol Manag 355: 83-90.

Chastain RA, Currie WS, Townsend PA. 2006. Carbon sequestration and nutrient cycling implications of the evergreen under story layer in Appalachian Forest. For Ecol Manag 231: 63-77.

Chauhan SK, Chauhan R. 2009. Exploring carbon sequestration in poplarwheat based integrated cropping system. Asia-Pacific Agrofor News 35: $9-10$

Chauhan SK, Sharma R, Singh B, Sharma SC. 2015. Biomass production, carbon sequestration and economics in on-farm poplar plantations in Punjab, India. Journal of Applied and Natural Science 7 (1): 452-458.

Chauhan SK, Sharma R, Panwar P, Chander J. 2016a. Short rotation forestry : a path for economic and environmental prosperity. In: Parthiban KT, Seenivasan R (eds.). Forestry Technologies - A Complete Value Chain Approach. Vol.1 Scientific Publishers, Jodhpur.

Chauhan SK, Ritu, Chauhan R. 2016b. Carbon sequestration in plantations. Agroforestry for increased production and livelihood security (Eds. Gupta, S.K., Panwar, P. and Kaushal, R.). New Indian Publishing Agency, New Delhi.

Crowley KF, Lovett GM, Arthur MA, Weathers KC. 2016. Long-term effects of pest-induced tree species change on carbon and nitrogen cycling in northeastern U.S. forests: A modeling analysis. For Ecol Manag 372: 269-290

Darch T, Martin SAB, Chadwick D, Haygarth PM, Hawkins JMB, Turner BL. 2016. Assessment of bioavailable organic phosphorus in tropical forest soils by organic acid extraction and phosphatase hydrolysis. Geoderma 284: 93-102.

Domec JC, Ward EJ, Oishi AC, Palmroth S, Radecki A, Bell DM, Miao G, Gavazzi M, Johnson DM, King JS, McNulty, SG, Oren R, Sun G, Noormets A. 2015. Conversion of natural forests to managed forest plantations decreases tree resistance to prolonged droughts. For Ecol Manag 355: 58-71.

Dunisch O, Eirbreich M, Eilers T. 2003. Water balance and water potentials of a monoculture and a enrichment plantation of Carapa guianensis Aubl. In the central Amazon. For Ecol Manag 172 (2-3): 355-367.

Galinato GI, Uchida S. 2010. Evaluating temporary certified emission reductions in reforestation and afforestation programs. Environ Resour Econ $46: 111-133$

Galinato GI, Uchida S. 2011. The effect of temporary certified emission reductions on forest rotations and carbon supply. Canadian J Agr Econ 59 (1): 145-164.

Gonzalez-Benecke CA, Samuelson LJ, Martin TA, Cropper Jr WP, Johnsen KH, Stokes TA, Butnor JR, Anderson PH. 2015. Modeling the effects of forest management on in situ and ex situ longleaf pine forest carbon stocks. For Ecol Manag 355: 24-36.
Grafen A, Hails R. 2002. Modern statistics for the life sciences. Oxford University Press, Oxford.

Groffman PM, Fisk MC. 2011. Phosphate addition have no effect on microbial biomass and activity in a northern hardwood forest. Soil Biol. Biochem. 43: 2441-2449.

Handayani. 2010. Regression models. STIE Atma Bhakti, Surakarta. [Indonesian]

Haneda NF, Raharjo SWB, Tiryana T, Seo JW, Susanti SC, 2012. Inventory of silvicultural practices, growth and pests of jabon planted for community forestry. Research report of SEAMEO BIOTROP, Bogor.

Hansen MC, Potapov PV, Moore R, Hancher M, Turubanova SA, Tyukavina A, Thau D, Stehman SV, Goetz, SJ, Loveland TR, Kommareddy A, Egorov, A, Chini L, Justice CO, Townshend JRG. 2013. High-resolution global maps of 21 st-century forest cover change. Science 342: 850-853.

Hardwick SR, Tuomi R, Pfeifer, Turner EC, Nilus R, Ewers RM. 2015. The relationship between leaf area index and microclimate in tropical forest and oil palm plantation: Forest disturbance drives changes in microclimate. Agric For Meteorol 201: 187-195.

Hawke DJ, Vallance JR. 2015. Microbial carbon concentration in samples of seabird and non-seabird forest soil: Implications for leaf litter cycling. Pedobiologia J Soil Ecol 58:33-39.

Herbst M, Mund M, Tamrakar R, Knohl A. 2015. Differences in carbon uptake and water use between a managed and an unmanaged beech forest in central Germany. For Ecol Manag 355: 101-108.

Hobara S, Osono T, Hirose D, Benner R. 2014. The role of microorganisms in litter decomposition and soil formation. Biogeochemistry 118: 471-486.

Indrayana Y, Siarudin M. 2013. Financial rotation of Jabon private forest in Pakenjeng, Garut, West Java. Jurnal Penelitian Hutan Tanaman 10 (4): 201-211. [Indonesian]

Kanninen M. 2010. Plantation forests: Global perspectives. In: Bauhus J, Meer PJ v.d., Kanninen M (eds.). Ecosystem Goods and Services from Plantation Forests. Earthscan, London.

Krisnawati HM, Kalliodan M, Kanninen. 2011. Anthocephalus cadamba Miq. Ecology, Silviculture, and Productivity. CIFOR. Bogor. Indonesia.

Laclau JP, Levillain J, Deleporte P, Nzila JD, Bouillet JP. Saint Andre L, Versini A, Mareschal L, Nouvellon Y, M'Bou AT, Ranger J. 2010. Organic residue mass at planting is an excellent predictor of tree growth in Eucalyptus plantations established on a sandy tropical soil. For Ecol Manag 260: 2148-2159.

Law BE., Waring, RH. 2015. Carbon implications of current and future effects of drought, fire and management on Pacific Northwest forests. For Ecol Manag 355: 4-14.

Liu L, Gundersen P, Zhang T, Mo J. 2012. Effect of phosphorus addition on soil microbial biomass and community composition in three forest type in tropical China. Soil Biol Biochem 44: 31-38.

Lu M, Yang Y, Li B. 2011. Responses of ecosystem nitrogen cycle to nitrogen addition: a meta-analysis. New Phytol 189: 1050-10509.

Mansur I, Tuheteru FD. 2011. Jabon Tree. Book. Penebar Swadaya. Jakarta. [Indonesian]

Martawijaya A, Kartasujana I, Mandang YI, Prawira SA, Kadir K. 1989. Wood Atlas of Indonesia. Volume II. Pusat Penelitian dan Pengembangan Hasil Hutan, Bogor. [Indonesian]

Millar CI, Stephenson NL, Stephens SL. 2007. Climate changes and forests of the future: managing in the face of uncertainty. Ecol Appl 17 (8): 2145-2151.

Murdiyarso D. 2003. Kyoto Protocol: Its Implications to the developing countries. Book. Publisher: Kompas Gramedia.

Noormets A, Epron D, Domec JC, McNulty SG, Fox TD, Chen J, Sun G, King JS. 2015. Effects of forest management on productivity and carbon sequestration: a review and hypothesis. For Ecol Manag 355: 124-140.

Olschewski R, Benitez PC. 2010. Optimizing joint production of timber and carbon sequestration of afforestation projects. J Forest Econ 16: 1-10.

Orwa C, Mutua A, Kindt R, Jamnadass R, Simons A. 2009. Agroforestree database: A tree reference and selection guide (version 4.0). World Agroforestry Centre (ICRAF), Nairobi, Kenya.

Panwar P, Chauhan S, Kaushal R, Das DK, Ajit, Arora G, Chaturvedi OP, Jain AK, Chaturvedi S, Tewari S 2017. Carbon sequestration potential of poplar-based agroforestry using the CO2FIX model in the IndoGangetic Region of India. Trop Ecol 58 (2): 1-9. 
Peters-Stanley M, Hamilton K, Yin D. 2012. Leveraging the landscape: State of the forest carbon markets 2012. In Ecosystem Marketplace.

Ruslim Y, Sihombing R, Liah Y. 2016. Stand damage due to mono-cable winch and bulldozer yarding in a selectively logged tropical forest. Biodiversitas 17 (1): 222-228.

Seo JW, Kim H, Chun JH, Mansur I, Lee CB. 2015. Silvicultural practice and growth of the jabon tree (Anthocephalus cadamba Miq.) in community forests of West Java, Indonesia. J Agr Life Sci 49 (4) 8193.

Sharma R, Chauhan SK, Tripathi AM. 2016. Carbon sequestration potential in agroforestry system in India: an analysis for carbon project. Agrofor Syst 90 (4):631-644.

Soerianegara I \&, Lemmens RHMJ. 1993. Plant resources of South-east Asia 5 (1): Timber trees: Major commercial timbers. Pudoc, Wageningen.

Tassone VC, Wesseler J, Nesci FS. 2004. Diverging incentives for afforestation from carbon sequestration: an economic analysis of the EU afforestation program in the south of Italy. For Pol Econ 6: 567578.

Tesfaye MA, Bravo F, Ruiz-Peinado R, Pando V, Bravo-Oviedo A. 2016 Impact of changes in land use, species and elevation on soil organic carbon and total nitrogen in Ethiopian Central Highlands. Geoderma 261: 70-79.

Tong S, Berry HL, Ebi K, Bambrick H, Hu W, Green D, Hanna E, Wang Z, Butler CD. 2016. Climate change, food, water and population health in China. Bull World Health Organ 94:759-765.

Turner BL, Wright SJ. 2014. The response of microbial biomass and hydrolytic enzymes to a decade of nitrogen, phosphorus and potassium addition in a lowland tropical land forest. Biogeochemistry 117: 115-130

Van Kooten GC, Binkley CS, Delcourt G. 1995. Effect of carbon taxes and subsidies on optimal forest rotation age and supply of carbon services. Am J Agric Econ 77: 365-374.

Van Gardingen PR, McLeish MJ, Philips PD, Fadilah D, Tyrie G, Yasman I. 2003. Financial and ecological analysis of management options for logged-over dipterocarp forest in Indonesia Borneo. For Ecol Manag 183: 1-29.

Waring BG, Powers JS. 2017. Overlooking what is underground: Root: shoot ratios and coarse root allometric equations for tropical forest. For Ecol Manag 385: 10-15.

Wunder, S. 2005. Payments for environmental services: Some nuts and bolts. Cifor Occasional Paper No. 42. Cifor, Bogor, Indonesia. 